\title{
PENERAPAN METODE PROBLEM BASED LEARNING DAN MEDIA GAMBAR DALAM PEMBELAJARAN MEMBACA CERITA
}

\author{
ASRI MUSANDI WARAULIA \\ Asrimusandi@yahoo.com \\ IKIP PGRI MADIUN
}

\begin{abstract}
This is qualitative description research about implementation of Problem Based Learning method and image media in learning Indonesian with reading material story. The purpose of this study, are: 1) describe the application of learning model Problem Based Learning and media images in reading story; 2) describe the involvement of the student, and 3) describe the ability to read stories fifth grade students of SDN Sambirejo 3. The subjects of this research were students and teachers Indonesian class V SDN Sambirejo 3 2015/2016 school year. Data collected through observation, interview, test, and document analysis. The validity of the data used two techniques, the triangulation of methods and triangulation of data sources. Comparative critical analysis technique is a technique of data analysis in this study. Application method of Problem Based Learning and Media Images in reading stories had some problems. These obstacles include: (1) the teacher has not been accustomed to in the application of methods, (2) the students still were not fully explore the capabilities of learning, and (3) time management was less appropriate. From learning activities that have been carried out, there was an excess obtained among other things, teachers were able to use the media images properly and the students also enjoyed using the learning with media images, as well as student activity developed well in the classroom. The final value of learning is as below the average value of 77.2 with the percentage of completeness $85 \%$ or 17 students. Based on the finding of research, it can be concluded that the implementation of Problem Based Learning method and the use of media images can make students active in learning and reading skills increased

Keywords: Reading Stories, Problem Based Learning, and Media Images.
\end{abstract}

\section{ABSTRAK}

Penelitian ini adalah penelitian deskripsi kualitatif yang berusaha untuk menerangkan penerapan metode Problem Based Learning dan media gambar dalam pembelajaran Bahasa Indonesia dengan materi membaca cerita. Tujuan penelitian ini 1) mendeskripsikan penerapan model pembelajaran Problem Based Learning dan media gambar dalam pembelajaran membaca cerita; 2) menjelaskan keaktifan siswa, dan 3) mendeskripsikan kemampuan membaca cerita siswa kelas V SDN Sambirejo 3. Subjek penelitian adalah siswa dan guru bahasa Indonesia kelas V SDN Sambirejo 3 tahun pelajaran 2015/2016. Data diperoleh melalui observasi, wawancara, tes, dan analisis dokumen. Validitas data menggunakan dua teknik, yakni triangulasi metode dan triangulasi sumber data. Teknik analisis kritis komparatif merupakan teknik analisis data pada penelitian ini. Penerapan metode problem Based Learning dan Media Gambar dalam pembelajaran membaca cerita mengalami beberapa kendala. Kendala tersebut antara lain (1) guru belum terbiasa dalam penerapan metode, (2) siswa masih belum sepenuhnya mengeksplor kemampuan dalam pembelajaran, serta (3) time management yang kurang sesuai saat pembelajaran. Dari kegiatan pembelajaran yang telah dilakukan, ada kelebihan yang didapat, antara lain, guru mampu menggunakan media gambar dengan baik dan siswa pun senang menggunakan pembelajaran dengan media gambar, serta keaktifan siswa dalam kelas terbangun dengan baik. Nilai akhir dari pembelajaran adalah sebagai berikut nilai rata-rata 77,2 dengan persentase ketuntasan $85 \%$ atau 17 siswa. Berdasarkan hal tersebut dapat disimpulkan bahwa penerapan metode Problem Based Learning dan penggunaan media gambar dapat membuat siswa aktif dan kemampuan membaca cerita siswa terasah dengan baik.

Kata Kunci: Membaca Cerita, Problem Based Learning, dan Media Gambar. 


\section{A. PENDAHULUAN}

Pembelajaran bahasa Indonesia terdiri dari empat keterampilan dasar. Empat keterampilan dasar tersebut yaitu keterampilan menyimak atau mendengarkan, berbicara, membaca, dan menulis. Membaca, khususnya membaca cerita anak merupakan bagian dari standar kompetensi yang harus dikuasai oleh siswa kelas $\mathrm{V}$ Sekolah Dasar, baik pada semester satu maupun dua. Pembelajaran ini bertujuan mengasah kemampuan, pemahaman, dan penalaran dari cerita yang disajikan. Siswa diharapkan mampu mengidentifikasi unsur instrinsik cerita, menceritakan kembali dengan kalimat sendiri, bahkan sampai memberi kritik mengenai cerita tersebut.

Membaca, adalah kegiatan yang penting untuk membangun mental penduduk dalam sebuah Negara. Mengingat pentingnya kebiasaan membaca, maka penanaman kebiasaan membaca pada jenjang Sekolah Dasar menjadi hal penting yang harus diperhatikan oleh semua pihak, terutama praktisi pendidikan. Kompetensi membaca sebaiknya dikemas dalam suatu kegiatan yang menyenangkan sehingga menjadi pengalaman yang benar-benar melekat pada pribadi anak sepanjang hayat. Kebiasaan pembelajaran membaca yang dilakukan dalam proses pembelajaran yaitu 1) salah satu siswa membaca cerita kemudian siswa lain mendengarkan; 2) siswa membaca cerita secara estafet, dibagi tiap siswa satu atau dua paragraf; 3) siswa membaca dalam hati (individu); dan 4) guru yang membaca cerita, sedangkan siswa mendengarkan. Cara keempat ini mendominasi dalam pembelajaran membaca di kelas. Problem Based Learning dan penerapan media gambar diharapkan dapat membuat siswa dapat berpikir kritis dan memiliki daya nalar tinggi dalam membaca cerita. Siswa lebih berperan aktif dalam pembelajaran, sedangkan guru hanya sebagai fasilitator. Hal ini dapat membentuk pembelajaran yang menyenangkan karena siswa merasa aktif berperan dalam pembelajaran.

Sejatinya pembelajaran sastra di Sekolah Dasar harus memberikan pengalaman pada murid yang berkontribusi pada empat tujuan, 1) pencarian kesenangan pada buku, 2) 
penginterpretasian bacaan sastra, 3) mengembangkan kesadaran bersastra, dan 4) mengembangkan apresiasi (Huck 1987 cit. Putra 2011). Jika hal ini dapat terwujud, maka pembelajaran kompetensi membaca dapat dikatakan berhasil. Salah satu metode yang dapat diterapkan dalam pembelajaran membaca ialah metode Problem Based Learning yang disinambungkan dengan penggunaan media gambar. Berdasar uraian di atas, dapat disimpulkan bahwa Problem Based Learning dinilai tepat untuk diterapkan dalam pembelajaran menulis teks berita.

\section{B. METODOLOGI PENELITIAN}

Penelitian dilaksanakan pada siswa kelas V SDN Sambirejo 3. Subjek penelitian adalah siswa dan guru bahasa Indonesia kelas V SDN Sambirejo 3 tahun pelajaran 2015/2016. Data penelitian dikumpulkan dari berbagai sumber yang meliputi: 1) Informan atau narasumber, yaitu siswa, guru, kepala sekolah; 2) Tempat dan peristiwa berlangsungnya aktivitas pembelajaran membaca dan aktivitas lain yang bertalian, dan; 3) Dokumen atau arsip, berupa silabus, Rencana
Pelaksanaan Pembelajaran (RPP), hasil tulisan siswa, dan buku penilaian.

Teknik yang digunakan untuk mengumpulkan data meliputi pengamatan, wawancara, analisis dokumen, dan angket. Validitas data menggunakan dua teknik, yakni triangulasi metode dan triangulasi sumber data. Teknik analisis kritis komparatif merupakan teknik analisis data pada penelitian ini. Dalam penelitian ini ada empat langkah dalam menganalisis data, yaitu 1) pengumpulan data; 2) reduksi data; 3) penyajian data; 4) penarikan simpulan. Ketiga komponen tersebut saling berkaitan dan tidak dapat dipisahkan. berikut adalah model analisis interaktif:

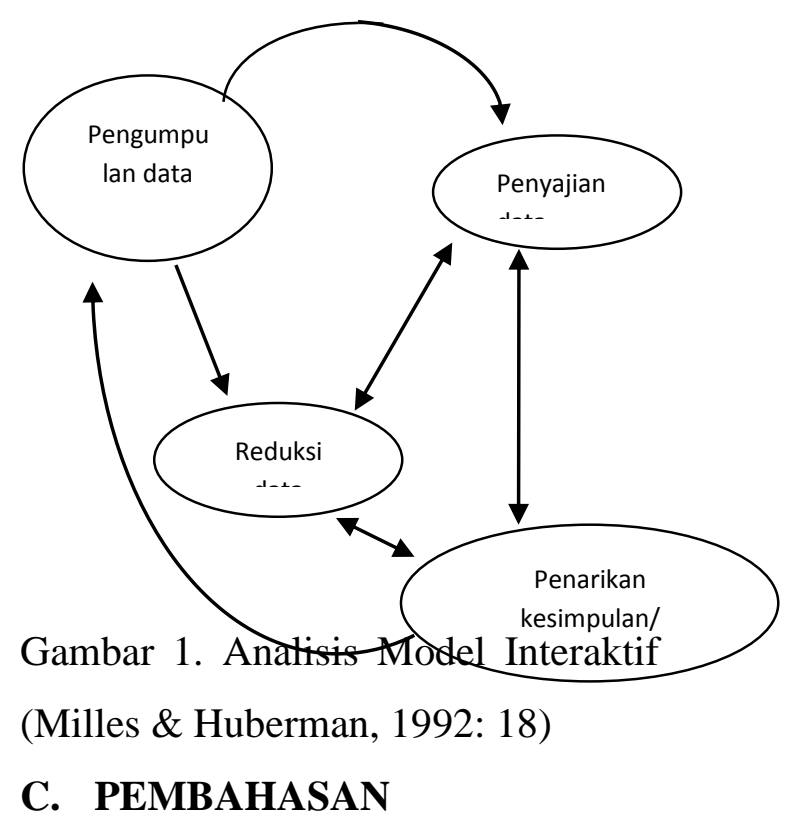


Pembelajaran yang bersifat pada pentingnya sebuah pembelajaran kritis hendaknya menggunakan melalui pengalaman, sehingga apa metode pembelajaran yang tepat yang dialami oleh siswa dapat dalam mengajarkannya. Salah satu dieksplorasi secara baik oleh mereka. pembelajaran yang dapat digunakan Hal ini dikarenakan, siswa aktif dalam ialah Problem Based Learning. Selain pembelajaran. Problem Based penerapan metode Problem Based Learning, pembelajaran menulis dapat menggunakan media gambar sebagai perangsang semangat siswa.

Menurut Rusman (2011:229), Problem Based Learning merupakan salah satu alternatif model pembelajaran yang memungkinkan dikembangkannya keterampilan berpikir siswa dalam memecahkan sebuah masalah. Keterampilan siswa tersebut mencakup penalaran, komunikasi, dan koneksi. Pada metode Problem Based Learning ini, siswa dituntut untuk mengembangkan kemampuan berpikirnya dengan mengoptimalkan proses kerja kelompok atau tim yang sistematis.

Pembelajaran model ini berdasar pada kajian seorang filsuf pendidikan pada tahun 1923, 1938 yakni John Dewey (David A. Jacobsen, Paul Enggen, dan Donal Kauchak, 2009:242). Menurut filsuf ini, Learning memiliki lima langkah dalam penerapannya (Trianto, 2007:71). Tahap pertama ialah siswa berorientasi pada masalah yang disajikan dengan media gambar. Selanjutnya, siswa mendeskripsikan dan mengorganisasikan tugas belajar. Tahap ketiga, siswa menyelidiki masalah. Tahap keempat, yakni mengembangkan dan menyajikan hasil karya. Tahap terakhir ialah menganalisis dan mengevaluasi proses pemecahan masalah.

Dalam pembelajaran ini, proses pembelajaran yang dilaksanakan guru dan siswa lebih berperan aktif dalam membaca cerita. Guru mengajak siswa untuk mengamati gambar yang menjadi sumber masalah, berpikir aktif dalam memecahkan masalah, dan akhirnya mampu membaca dengan runtut dari informasi yang dikumpulkan siswa.

Problem Based Learning menekankan 
Tahap perencanaan tindakan Pelaksanaan Pembelajaran (RPP) pembelajaran meliputi lima kegiatan materi membaca cerita serta diimbangi utama. Kegiatan-kegiatan tersebut dengan pembuatan media gambar. adalah 1) mengevaluasi ulang Penyusunan RPP dan media yang kekurang-kekurang pembelajaran dilakukan oleh guru haruslah sejalan sebelumnya, 2) merancang skenario pembelajaran, 3) menyusun RPP, 4) mempersiapkan media pembelajaran, dan 5) instrument penelitian. Kekurangan-kekurang yang muncul di pembelajaran sebelumnya dikaji dan dievaluasi untuk menemukan pemecahannya. Selanjutnya, kegiatan perencanaan tindakan pembelajaran ialah merancang skenario pembelajaran berdasar evaluasi yang telah dilakukan pada pembelajaran sebelumnya. Skenario ini didiskusikan antara peneliti dan guru Bahasa Indonesia dengan tujuan agar terbentuknya kesepakatan dan kesepahaman tentang pembelajaran membaca cerita dengan metode Problem Based Learning dan penggunaan media gambar yang baik, sehingga kekurangan-kekurangan yang muncul di pembelajaran sebelumnya tidak terulang lagi.

Setelah skenario dirumuskan secara bersama, guru bertanggung jawab untuk menyusun Rencana dengan skenario yang telah dibahas bersama oleh guru dan peneliti. Guru membuat empat rangkaian media gambar yang berbeda. Gambar yang dibuat oleh guru sebagai media, nantinya akan digunakan oleh masingmasing kelompok berbeda-beda. Satu kelas terdiri dari empat kelompok, sehingga gambar yang digunakan ada empat rangkaian.

Kegiatan terakhir dalam perencanaan pembelajaran ialah menyusun dan mempersiapkan instrumen penelitian. Instrumen penelitian terdiri dari dua, yakni tes dan nontes. Instrumen tes digunakan untuk menilai hasil pekerjaan siswa dalam membaca cerita dengan metode Problem Based Learning dan penggunaan media gambar. Instrumen nontes dinilai berdasarkan pedoman observasi keaktifan siswa, jurnal refleksi siswa, dan jurnal refleksi guru.

\section{Pelaksanaan Pembelajaran}


Pelaksanaan pembelajaran yang teridiri dari dua pertemuan disesuaikan skenario dan RPP yang telah dibuat dengan kegiatan utamanya adalah siswa mengamati gambar, menentukan kerangka, mencari informasi, dan membaca cerita dari informasi yang didapat. Tiga kegiatan utama dalam pembelajaran, baik pertemuan pertama dan kedua ialah kegiatan awal, inti, dan kegiatan akhir.

Kegiatan pertemuan pertama diawali guru membuka pelajaran dengan ucapan salam. Siswa menjawab dengan serentak. Guru bertanya keadaan siswa. Semua siswa menjawab dengan semangat, "Baik Bu....”. Setelah menyapa siswa, guru berdiri di tengah dan menanyakan kepada siswa tentang membaca cerita. Siswa menjawab bahwa mereka tidak membaca cerita lagi. Namun, ada dua siswa yang menjawab dengan diberi tambahan.

Siswa memperhatikan penjelasan guru tentang pengertian cerita dan macam-macam cerita merupakan awal kegiatan inti. Guru memberikan contoh-contoh cerita kepada siswa. Siswa memperhatikan dengan seksama. Seorang siswa bertanya kepada guru, karena kurang jelas. Siswa tersebut adalah Difta. Guru menjawab pertanyaan Difta hingga dia merasa jelas. Setelah penjelasan dirasa cukup dan tidak ada yang bertanya lagi, pembelajaran dilanjutkan ke kegiatan berikutnya. Guru membagi siswa menjadi empat kelompok. Masing-masing kelompok terdiri dari lima siswa. Pembagian kelompok dilakukan secara acak tidak ada ketentuan.

Setelah siswa berkumpul dengan kelompoknya, guru memberikan rangkaian media gambar yang sudah dipersiapkan. Masing-masing kelompok mengamati gambar dengan cermat. Masing-masing anggota kelompok menebak cerita apa yang akan dibaca, siapa saja tokohnya, dan alur dari ceritanya. Setelah itu, guru membagikan teks cerita di masingmasing kelompok. Secara bergantian, siswa dalam kelompok membaca cerita. Setiap selesai membaca cerita, siswa dalam keompok bertugas untuk mencocokkan dengan gambar yang telah dibagikan sebelumnya.

Di akhir kegiatan, guru memberikan kesempatan kepada siswa 
untuk bertanya bila belum mengerti. Guru menjelaskan gambaran tentang kegiatan yang akan dilakukan siswa pada pertemuan berikutnya dengan tujuan agar siswa memiliki gambaran kegiatan yang akan dilaksanakan. Akhirnya, guru mengajak siswa untuk menyimpulkan kegiatan pembelajaran yang telah dilaksanakan. Pembelajaran ditutup dengan salam oleh guru.

Sama halnya dengan pertemuan pertama, pertemuan kedua pembelajaran terdiri dari tiga kegiatan pokok, yakni kegiatan awal, inti, dan kegiatan akhir. Guru memberi salam dan membimbing berdoa bersama di awal pertemuan. Selanjutnya, guru memberikan pertanyaan mengenai kegiatan-kegiatan yang telah dilaksanakan pada pertemuan pertama. Siswa antusias menjawab pertanyaan tersebut, dan akhirnya sedikit gaduh. Guru menenangkan dan meminta siswa yang akan mengemukakan pendapat tunjuk jari. Lima orang anak mengangkat tangan mereka.

Kegiatan inti diawali oleh siswa berkumpul dengan kelompoknya, mengamati kembali gambar dan cerita yang telah dibaca, apakah sudah sesuai atau belum. Jika belum yakin dengan kerangka yang ditulis, mereka dapat memperbaikinya. Selama \pm 10 menit berdiskusi, semua kelompok yakin. Setelah itu, guru memberikan arahan kepada siswa bagaimana tata cara menentukan unsur instriksik cerita. Setelah semua jelas, siswa dalam kelompok menerima beberapa gambar dan bekerja sama menuliskan unsur instrinsik cerita serta menepelkan gambar yang sesuai dengan apa yang ditulisnya. Penulisan hasil membaca dibuat sebagus dan semenarik mungkin, karena akan dipajang di majalah dinding kelas.

Kegiatan membaca cerita, menuliskan unsur cerita, dan merevisi kembali berlangsung selama \pm 30 menit. Siswa yang sudah menyelesaikan tulisannya, langsung menempelkan tulisannya di madding kelas. Setelah semua siswa menempelkan hasil kerja kelompoknya, guru menyuruh siswa untuk mengamati dan membaca hasilnya tersebut. Guru memberikan kesempatan kepada semua siswa untuk mengemukakan pendapat dan penilaian terhadap hasil membaca 
yang dipajang. Guru memimpin siswa untuk menentukan dua hasil kerja kelompok yang paling baik. Guru mengajak siswa untuk memberikan penghargaan kepada pemenang yakni dengan bertepuk tangan. Semua siswa bertepuk tangan dengan ceria.

Pembelajaran diakhiri dengan menyimpulkan pembelajaran yang telah dilakukan. Ada lima siswa yang mengemukakan simpulannya. Guru menutup pertemuan dengan mengucapkan salam dan memberikan pesan agar siswa tetap rajin belajar.

\section{Observasi dan Evaluasi}

Peneliti mengamati jalannya pembelajaran membaca cerita dengan metode Problem Based Learning dan penggunaan media gambar siswa kelas V SDN Sambirejo 3 dengan menjadi partisipasi aktif dan berada di dalam kelas. Pembelajaran pembelajaran yang berlangsung selama 4 x 35 menit, mempelajari hakikat cerita, macammacam cerita, dan contoh cerita, serta bagaimana menentukan unsur cerita.

Siswa sangat antusias mengikuti pembelajaran membaca cerita dengan metode Problem Based Learning dan penggunaan media gambar. Diskusi kelompok sudah berjalan lancar dan semua siswa berperan aktif di dalamnya. Keaktifan siswa dalam diskusi kelompok dapat dilihat dari hasil pengamatan peneliti saat pembelajaran membaca cerita dengan metode Problem Based Learning dan penggunaan media gambar.

Dari kegiatan pembelajaran dapat dijelaskan keaktifan siswa dalam pembelajaran membaca cerita dengan metode Problem Based Learning dan penggunaan media gambar. Siswa cukup baik dalam memerhatikan penjelasan guru dan gambar yang mereka dapat. Siswa termotivasi untuk memperhatikan gambar dengan seksama. Siswa cukup bersemangat dalam bekerjasama untuk mendiskusikan tugas-tugas secara berkelompok. Semua anggota kelompok berperan aktif dalam merumuskan unsur instrinsik cerita. Saat bekerja kelompok, siswa kondusif dan tenang. Kesempatan untuk bertanya jika belum mengerti yang diberikan oleh guru dimanfaatkan oleh empat orang siswa. Di akhir pembelajaran, lima siswa termotivasi untuk menyimpulkan kegiatan pembelajaran yang telah dilaksanakan. 


\begin{abstract}
Kegiatan terakhir ialah aktif dalam membaca cerita, mempublikasikan. Siswa sangat mendiskusikan unsur instrinsik cerita, antusias untuk mempublikasikan hasil dan memajang hasil diskusi di diskusi yang telah mereka tulis dengan madding kelas. Nilai akhir 17 siswa cara memajang di mading kelas. Siswa juga menghias hasil kerja kelompok dengan gambar yang mereka buat dan pita-pita kecil sehingga terlihat lebih indah. Setelah dipajang, semua siswa menentukan dua yang paling bagus, baik dari segi isi, bahasa, dan ejaan.

Selain dari observasi saat pembelajaran, kemampuan membaca cerita dapat dilihat dari jurnal refleksi siswa dan guru. Siswa kelas V SDN Sambirejo 3 sudah mulai memahami pembelajaran membaca cerita dengan dalam pembelajaran membaca cerita sudah mencapai KKM yang telah ditentukan. Hasil pekerjaan siswa tersebut dapat diidentifikasi sebagai berikut. Rata-rata nilai siswa dalam kegiatan membaca cerita sudah memenuhi KKM yakni 77,2. Nilai terendah 69 dan nilai tertinggi 84 .

Pada pembelajaran jumlah siswa yang memperoleh nilai sama atau di atas KKM (75) adalah 17 siswa (85\%) dari 20 siswa kelas V SDN Sambirejo 3.
\end{abstract} metode Problem Based Learning dan penggunaan media gambar. Hal ini dibuktikan dengan meningkatnya hasil akhir pembelajaran membaca cerita pembelajaran bila dibandingkan pembelajaran sebelumnya. Nilai ratarata pada pembelajaran lebih tinggi dari pembelajaran sebelumnya yakni 77,2 . Berdasarkan jurnal refleksi guru dalam pelaksanaan pembelajaran, penerapan metode Problem Based Learning dan penggunaan media gambar dalam pembelajaran membaca cerita berjalan dengan optimal. Siswa

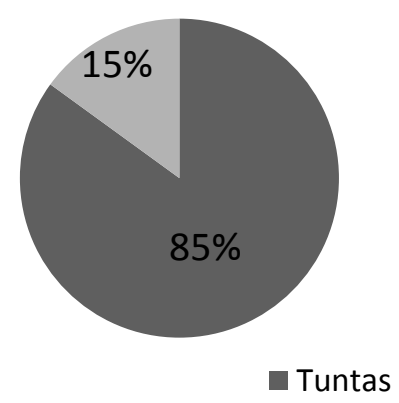

Gambar 2. Diagram Ketuntasan Belajar Pembelajaran 


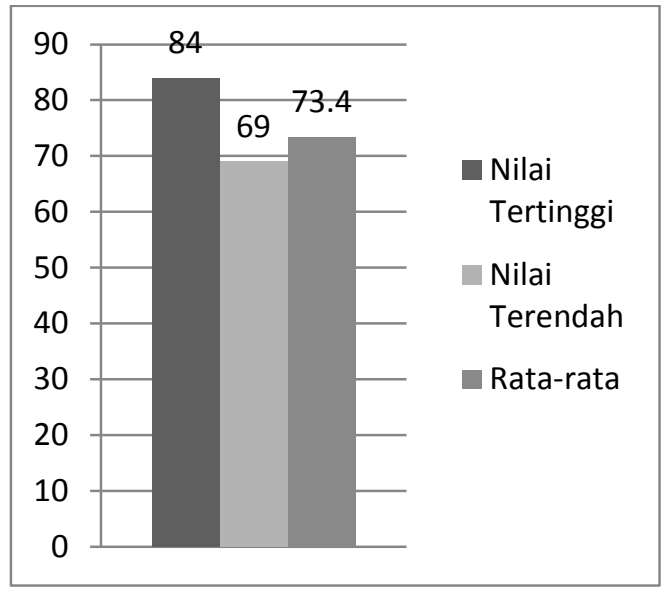

Gambar 3. Diagram Perolehan Nilai Kemampuan Membaca cerita Pembelajaran

\section{Analisis dan Refleksi Tindakan Pembelajaran}

Secara umum, proses pembelajaran membaca cerita dengan metode Problem Based Learning dan penggunaan media gambar pada pembelajaran berjalan dengan lancar. Pembelajaran membaca cerita mengalami peningkatan dalam segi proses dan hasilnya. Hal tersebut merupakan kelebihan dari pembelajaran membaca cerita yang dilaksanakan dengan menerapkan metode Problem Based Learning dan penggunaan media gambar. Guru semakin mahir menerapkan metode Problem Based Learning dalam pembelajaran membaca cerita dan menggunakan media gambar yang dipersiapkan sendiri dalam pembelajaran membaca cerita. Siswa berani bertanya dan mengemukakan pendapat. Selain itu, siswa juga telah mampu membaca cerita sekaligus menentukan unsur intrinsiknya.

Nilai rata-rata kelas mengalami peningkatan menjadi 77,2. Siswa yang telah tuntas mencapai $85 \%$. Berdasarkan hal tersebut, maka tujuan yang ingin dicapai dalam pembelajaran membaca cerita telah terpenuhi. Dengan demikian, kegiatan pembelajaran membaca cerita telah mengalami peningkatan baik dari segi kualitas proses dan kemampuan membaca cerita siswa.

\section{PENUTUP}

Berdasar hasil penelitian yang telah dilaksanakan dan pembahasan yang telah dilakukan, dapat diambil dua simpulan besar sebagai berikut. Pertama, penerapan metode Problem Based Learning dan penggunaan media gambar dapat menumbuhkan keaktifan siswa kelas $\mathrm{V}$ SDN Sambirejo 3 dalam pembelajaran membaca cerita. Hal ini dapat dilihat dari (a) siswa aktif dalam mendengarkan penjelakan guru; (b) siswa mampu menemukan masalah dengan mengamati gambar; (c) siswa 
mampu memecahkan masalah dengan mencari informasi dan materi untuk membaca cerita; (d) siswa mampu mengomentari dan mengemukakan pendapat terhadap hasil kerja yang ditulis teman; (e) siswa tidak canggung lagi bertanya bila belum mengerti; dan (f) siswa mampu membaca cerita dengan baik. Kedua, penerapan metode Problem Based Learning dan penggunaan media gambar didapatkan nilai akhir dari pembelajaran adalah sebagai berikut.

Nilai rata-rata 77,2 dengan persentase ketuntasan $85 \%$ atau 17 siswa. Berdasarkan hal tersebut dapat disimpulkan bahwa penerapan metode Problem Based Learning dan penggunaan media gambar dapat membuat siswa aktif dan kemampuan membaca cerita siswa terasah dengan baik.

Walaupun pembelajaran yang digambarkan di atas tidak mudah untuk diciptakan dan dilaksanakan, setidak-tidaknya guru harus dapat memberikan ruang gerak yang lebih luas demi kepentingan semangat siswa dalam mengikuti pembelajaran. Hal yang tidak dapat diremehkan bagi perkembangan semangat dan gairah belajar siswa adalah apakah pada diri guru terlihat adanya suatu sikap yang memiliki daya tarik. Hal ini dapat terjadi jika guru merasa tergerak berada di tengah-tengah mata pelajaran tersebut. Contoh sikap yang diperlihatkan oleh seorang guru memiliki peranan penting. Sebaliknya, guru yang tidak merasa tertarik dan tidak menaruh perhatian terhadap sesuatu, serta tidak disukai siswa, akan sukar merangsang timbulnya keinginan siswa untuk mau belajar. Dengan penyampaian guru yang menarik, maka keaktifan siswa akan meningkat. Begitu juga sebaliknya.

Pembelajaran dengan media gambar yang ditetapkan untuk meningkatkan kemampuan siswa dalam membaca cerita adalah upaya guru untuk memfasilitasi siswa dalam belajar sehingga siswa tertarik dan akhirnya aktif dalam pembelajaran. Siswa yang biasanya hanya pasif menerima pelajaran menurut perintah atau petunjuk guru, berubah menjadi siswa yang aktif menentukan sendiri bagaimana langkah-langkah membaca cerita sesuai dengan gambar yang disajikan tanpa banyak interversi oleh guru. Dengan demikian, siswa lebih 
aktif melakukan praktik membaca cerita. Pada akhir pembelajaran, siswa dapat merefleksikan bahwa membaca cerita dengan metode Problem Based Learning dan menggunakan media gambar bukanlah hal yang membosankan. Bahkan, siswa semangat dan bergairah dalam mengikuti proses pembelajaran. Hal ini berpengaruh positif terhadap hasil pembelajaran sehingga akan terjadi peningkatan kemaampuan siswa dalam membaca cerita.

Pembelajaran membaca cerita dengan metode Problem Based Learning dan penggunaan media gambar merupakan pembelajaran yang mengutamakan kerja sama, diskusi kelompok, saling berpartisipasi, saling berusaha membantu, saling mendengarkan, saling memuji, saling bertanya, saling memperhatikan sehingga suasana pembelajaran tampak menyenangkan, tidak membosankan, belajar dengan bergairah, pembelajaran aktifresponsif, siswa aktif dan kritis, serta guru kreatif. Mengingat penerapan metode Problem Based Learning dan penggunaan media gambar dapat meningkatkan kemampuan membaca cerita siswa, maka diharapkan metode dan media tersebut dapat diterapkan di dalam pembelajaran, khususnya pembelajaran membaca cerita.

\section{DAFTAR PUSTAKA}

Arief Sadiman. 2007. Media Pendidikan. Jakarta: Raja Grafindo Persada.

Azhar Arsyad. 2007. Media Pembelajaran. Jakarta : Raja Grafindo.

Burhan Nurgiyantoro. 2010. Penilaian Pembelajaran Bahasa. Yogyakarta: BPFEYOGYAKARTA.

Eko Putro Widoyoko. 2009. Evaluasi Program Pembelajaran. Yogyakarta: Pustaka Pelajar.

Hardjana, H. P. 2006. Cara Mudah Mengarang Cerita Anak-anak. Jakarta: Grasindo.

Jacobsen, David A, Paul Eggen, dan Donald Kauchak diterjemahkan oleh Achmad Fawaid dan Khoirul Anam. 2009. Methods for Teaching. Yogyakarta: Pustaka Pelajar.

Milles dan Hubbermain. 1992. Miles, M. B. dan A. M. Hubermain. 1992. Analisis Data Kualitatif: Buku Sumber Tentang Metode-metode Baru (Judul Asli: Qualitative Data Analysis. Diterjemahkan oleh Tjetjep Rohandi Rohidi). Jakarta: UI Press. 
Nana Sudjana dan Ahmad Rivai. 2002. Media Pengajaran. Bandung: Sinar Baru Algesindo.

Nurgiyantoro, Burhan. 2005. Sastra Anak: Pengantar Pemahaman Dunia Anak. Yogyakarta:

Gajah Mada University Press.

Oster, Leslie. 2001. Using the Think Aloud for Reading Instruction. The Reading Teacher. Vol. 5 No. 1. Halaman 64-69.

Rusman. 2011. Model-model Pembelajaran. Jakarta: PT RajaGrafindo Persada.

Sagala, Syaiful. 2007. Konsep dan Makna Pembelajaran. Bandung: Alfabeta. 